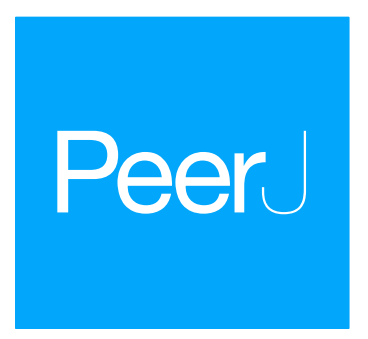

Submitted 21 February 2018

Accepted 30 April 2018

Published 22 May 2018

Corresponding author

Tanvir Shahzad,

hereistanvir@gmail.com

Academic editor

Melanie Kah

Additional Information and Declarations can be found on page 9

DOI $10.7717 /$ peerj.4802

Copyright

2018 Rehman et al.

Distributed under

Creative Commons CC-BY 4.0

OPEN ACCESS

\section{Effect of Reactive Black 5 azo dye on soil processes related to $\mathrm{C}$ and $\mathrm{N}$ cycling}

\author{
Khadeeja Rehman ${ }^{1}$, Tanvir Shahzad ${ }^{1}$, Amna Sahar ${ }^{2}$, Sabir Hussain ${ }^{1}$, \\ Faisal Mahmood $^{1}$, Muhammad H. Siddique ${ }^{3}$, Muhammad A. Siddique ${ }^{1}$ and \\ Muhammad I. Rashid ${ }^{4,5}$ \\ ${ }^{1}$ Environmental Sciences \& Engineering, Government College University, Faisalabad, Pakistan \\ ${ }^{2}$ Department of Food Engineering, National Institute of Food Science and Technology, University of \\ Agriculture Faisalabad, Faisalabad, Pakistan \\ ${ }^{3}$ Department of Bioinformatics and Biotechnology, Government College University, Faisalabad, Pakistan \\ ${ }^{4}$ Center of Excellence in Environmental Sciences, King Abdul Aziz University, Jeddah, Saudi Arabia \\ ${ }^{5}$ Department of Environmental Sciences, COMSATS Institute of Information Technology, Vehari Campus, \\ Vehari, Pakistan
}

\section{ABSTRACT}

Azo dyes are one of the largest classes of synthetic dyes being used in textile industries. It has been reported that $15-50 \%$ of these dyes find their way into wastewater that is often used for irrigation purpose in developing countries. The effect of azo dyes contamination on soil nitrogen $(\mathrm{N})$ has been studied previously. However, how does the azo dye contamination affect soil carbon (C) cycling is unknown. Therefore, we assessed the effect of azo dye contamination (Reactive Black 5, $30 \mathrm{mg} \mathrm{kg}^{-1}$ dry soil), bacteria that decolorize this dye and dye + bacteria in the presence or absence of maize leaf litter on soil respiration, soil inorganic $\mathrm{N}$ and microbial biomass. We found that dye contamination did not induce any change in soil respiration, soil microbial biomass or soil inorganic $\mathrm{N}$ availability $(P>0.05)$. Litter evidently increased soil respiration. Our study concludes that the Reactive Black 5 azo dye (applied in low amount, i.e., $30 \mathrm{mg} \mathrm{kg}^{-1}$ dry soil) contamination did not modify organic matter decomposition, $\mathrm{N}$ mineralization and microbial biomass in a silty loam soil.

Subjects Soil Science, Environmental Impacts

Keywords Soil respiration, Litter amendment, Soil contamination, Soil microbial biomass, Azo dye contamination

\section{INTRODUCTION}

Azo dyes, which contain one or more than one $-\mathrm{N}=\mathrm{N}$ - groups, constitute the largest class of synthetic dyes that are used in a wide range of commercial applications, i.e., textile, food, paper printing, cosmetics with textile industry as the largest consumer (O'Neill et al., 1999). It has been reported that $15-50 \%$ of the applied azo dyes do not bind to the fabric during the dyeing process and are released into wastewater (McMullan et al., 2001). The concentration of the azo dyes in textile wastewaters vary from 10 to $250 \mathrm{mg} \mathrm{L}^{-1}$ (O'Neill et al. 1999). Presence of azo dyes in water bodies causes aesthetic problems and obstruct light penetration and oxygen transfer into water thereby affecting aquatic life (Sponza, 2006; Li et al., 2012; Zhang et al., 2012). Azo dyes and their degradation intermediates may also be mutagenic and carcinogenic for living organisms (Weisburger, 2002). In fact, the toxicity 
and ecological harm caused by organic dyes is much larger than that is caused by other organic pollutants such as PAHs and PCBs making them very important class of pollutants (Zhou, 2001).

Using the dye-containing textile wastewater for soil irrigation purposes around big cities is a common practice in developing countries (Ensink et al., 2004; Ensink, Van der Hoek $\&$ Amerasinghe, 2006; Faryal, Tahir \& Hameed, 2007; Garg \& Kaushik, 2008). Therefore, a large concentration of azo dyes can accumulate in surface soils particularly around textile processing units. For example, Zhou (2001) reported that on average $12.3-456.2 \mathrm{mg} \mathrm{kg}^{-1}$ soil of azo dyes were present in surface soils near dyeing and printing industry units. The dyes can stabilize in soil colloid within a few weeks and are retained in the soils for long term (Imran et al., 2015). In soils, they negatively affect germination rates as well as overall growth of plants (Cicek et al., 2012; Vafaei et al., 2012). There are a number of studies that have investigated soil processes to find the mechanistic basis for negative effect of azo dyes on plant growth and germination (Gupte, Keharia \& Gupte, 2013; Imran et al., 2015; Mahmood et al., 2017; Shafqat et al., 2017).

For example, $\mathrm{NH}_{4}^{+}-\mathrm{N}$ oxidation potential, arginine ammonification rate and potential nitrification rates have been found to decrease after the soils were spiked with azo dyes (Topaç et al., 2009; Batool et al., 2015). Moreover, microorganisms involved in nitrogen (N) transformation events such as nitrobacter and ammonia-oxidizing bacteria as well as activity of $\mathrm{N}$ cycling enzyme urease have also been shown to decrease significantly in the presence of azo dyes (Oranusi \& Ogugbue, 2002; Topaç et al., 2009; Batool et al., 2015). While soil $\mathrm{N}$ cycling in response to azo dye pollution has been investigated previously (Topaç et al., 2009; Batool et al., 2015), soil carbon (C) cycling which is closely coupled to $\mathrm{N}$ cycling and is primordially important for soil functioning has not been studied at all.

It has become a common practice to add organics to soils contaminated by hydrocarbons for their bioremediation (Lal, 2004; Gärdenäs et al., 2011; Shahzad et al., 2012). Organic amendments to soils immobilize hydrocarbon pollutants and reduce the negative effects on soil microbial pollutions and enzyme activities probably due to the role of organic matter in sorption of organic pollutants (Maliszewska-Kordybach \& Smreczak, 2000; Tejada et al., 2008; Lee, Oh \& Kim, 2008). How well an organic amendment to a soil contaminated with azo dyes improves the soil functions and alleviates its negative effects remains unknown.

Bioremediation of azo dyes in textile waste effluents in liquid media by bacteria has been widely studied (Khalid, Arshad \& Crowley, 2008; Khalid et al., 2013; Hussain et al., 2013; Anwar et al., 2014; Najme et al., 2015). Several species of bacteria have been identified which decolorize azo dyes (Pandey, Singh \& Iyengar, 2007; Hussain et al., 2013). Bacteria can even degrade intermediate products of decolorization such as aromatic amines with the help of enzymes like hydroxylase and oxygenase (Pandey, Singh \& Iyengar, 2007), thus aiding in reducing lethal effects of azo dyes by formation of non-toxic metabolites. Despite this large number of studies reporting the potential of bacteria to transform azo dyes into non-toxic metabolites in liquid media, the evaluation of such bacteria to detoxify an azo dye in soil has rarely been assessed.

This study was designed to investigate the effect of an azo dye Reactive Black 5 (RB5) contamination on soil respiration, microbial biomass and net mineral $\mathrm{N}$ (ammonium \& 
nitrate) in the presence or absence of litter and a bacterial species known to decolorize RB5 (Hussain et al., 2013).

\section{MATERIALS \& METHODS}

\section{Soil respiration}

Soil was sampled from a non-contaminated irrigated agricultural field of experimental area of Ayub Agriculture Research Farm Faisalabad, that has been under wheat-fallow rotation for more than fifteen years. The upper $0-15 \mathrm{~cm}$ was sampled and sieved at $2 \mathrm{~mm}$. Physico-chemical characteristics of the soil were determined (Table 1). Microcosms containing soil in sealed mason jars were prepared to measure soil C mineralization. Briefly, fifty grams (dry equivalent) of fresh soil of known water holding capacity (WHC, amount of water that a soil can hold at atmospheric pressure against gravity) and moisture content were put in a $100 \mathrm{ml}$ beaker that was sealed in a $1 \mathrm{~L}$ mason jar. A test tube containing $40 \mathrm{ml} 0.05 \mathrm{M} \mathrm{NaOH}$ was also placed inside jar to capture the $\mathrm{CO}_{2}$ evolved from the soil. Moreover, a test tube containing distilled water was also placed inside the jar to avoid the inside air from drying. Nine treatments of the study are given in Table 2.

Dye was mixed in ultra-pure water before being added to soil at the rate of $30 \mathrm{mg} \mathrm{kg}^{-1}$ soil. This rate of the azo dye was selected based on the average amount of it found in peri-urban soils of Faisalabad (study location) that are irrigated with textile wastewater (S Hussain, pers. comm., 2015). The strain RA20 (Pseudomonas sp.) was grown in MS medium (Hussain et al., 2013) and, after $24 \mathrm{~h}$, the bacteria were harvested by centrifugation (6,000 rpm for $5 \mathrm{~min}$ ), washed twice then re-suspended in water. This bacterial suspension was inoculated in the soil as per treatment plan. Senesced maize leaves were ground in a ball mill and added to relevant treatments at the rate of $1 \mathrm{~g} \mathrm{C} \mathrm{kg}^{-1}$ soil. Soil moisture content was maintained at $60 \%$ of the field capacity in all the treatments throughout the experimental duration of 29 days.

Soil respiration was measured by taking the $\mathrm{NaOH}$ traps out at regular intervals and concentration of $\mathrm{CO}_{2}$ evolved from soils was determined by a modified Isermeyer method (Isermeyer, 1952; Jaggi, 1976). Briefly, concentration of $\mathrm{CO}_{2}$ in $\mathrm{NaOH}$ was precipitated with $0.5 \mathrm{M} \mathrm{BaCl}_{2}$ followed by titration against $0.1 \mathrm{M} \mathrm{HCl}$ using phenolphthalein as indicator. At each gas sampling day, glass vials with fresh $\mathrm{NaOH}$ were placed and soil moisture content of soils were maintained at $60 \%$ of WHC by adding ultra-pure water when required. The lost water in soils was determined by weighing the soils packed in beakers.

\section{Soil variables}

After 29 days of soil incubation, the experimental units were harvested for destructive sampling of soil and various soil variables were determined. Water extractable organic carbon (WEOC) of the soil was determined using the wet dichromate oxidation procedure described by Nelson \& Sommers (1982). Briefly, $5 \mathrm{~g}$ of the incubated soil were shaken in $20 \mathrm{ml}$ of ultra-pure water end over end for half an hour, centrifuged at 3,000 rpm and filtered. Four $\mathrm{ml}$ of the extract was taken and $1 \mathrm{ml}$ of $1 \mathrm{M} \mathrm{K}_{2} \mathrm{Cr}_{2} \mathrm{O}_{7}, 5 \mathrm{ml}$ of concentrated $\mathrm{H}_{2} \mathrm{SO}_{4}$, and 2 drops of o-phenathroline monohydrate were added to it. The digests were then titrated against $0.033 \mathrm{M}$ standardized ferrous ammonium sulphate. 


\begin{tabular}{ll} 
Table $1 \quad$ Physico-chemical properties of the soil used in the experiment. & \\
Property & Value \\
\hline Soil texture & Silt loam \\
Sand $(\%)$ & 25 \\
Silt $(\%)$ & 55 \\
Clay (\%) & 20 \\
pH (1:2.5 soil to water) & $8.32 \pm 0.06$ \\
Electrical conductivity $\left(\mu \mathrm{S} \mathrm{cm}^{-1}\right)$ & 1,151 \\
Soil organic carbon $\left(\mathrm{g} \mathrm{kg}^{-1} \mathrm{soil}^{\prime}\right)$ & $8.66 \pm 0.43$ \\
\hline
\end{tabular}

Table 2 Details of the soil treatments used in the experiment.

\begin{tabular}{|c|c|}
\hline Treatment name & Description/Dose \\
\hline 1. Control & Soil without any amendment. \\
\hline 2. Dye treatment & Soil spiked with Reactive Black 5 Dye (RB 5, $30 \mathrm{mg} \mathrm{kg}^{-1}$ soil). \\
\hline 3. Bacteria treatment & Soil inoculated with Pseudomonas sp. RA20 (Hussain et al., 2013). \\
\hline 4. Dye + bacteria treatment & $\begin{array}{l}\text { Soil spiked with RB } 5 \text { ( } 30 \mathrm{mg} \mathrm{kg}^{-1} \text { soil) as well as inoculated with } \\
\text { Pseudomonas sp. RA20. }\end{array}$ \\
\hline 5. Litter treatment & Soil amended with maize litter ( $1 \mathrm{~g} \mathrm{C} \mathrm{kg}^{-1}$ soil). \\
\hline 6. Dye + litter treatment & $\begin{array}{l}\text { Soil amended with RB } 5 \text { ( } 30 \mathrm{mg} \mathrm{kg}^{-1} \text { soil) and maize litter (1 g C } \\
\mathrm{kg}^{-1} \text { soil). }\end{array}$ \\
\hline 7. Dye + litter + bacteria treatment & $\begin{array}{l}\text { Soil amended with RB } 5 \text { ( } 30 \mathrm{mg} \mathrm{kg}^{-1} \text { soil) and maize litter ( } 1 \mathrm{~g} \mathrm{C} \\
\mathrm{kg}^{-1} \text { soil) and inoculated with Pseudomonas sp. RA20. }\end{array}$ \\
\hline
\end{tabular}

Microbial biomass was determined using the fumigation-extraction method (Vance, Brookes \& Jenkinson, 1987). Briefly, $10 \mathrm{~g}$ of soil was fumigated in the presence of fuming chloroform in an air-free desiccator for $24 \mathrm{~h}$. Soils were then extracted with $40 \mathrm{ml}$ of 0.5 $\mathrm{M} \mathrm{K}_{2} \mathrm{SO}_{4}$ after shaking the mixture end over end for one hour. The extract was digested with potassium dichromate and concentrated sulphuric acid. The digests were then titrated against standardized ferrous ammonium sulphate after adding couple of drops of the indicator o-phenathroline monohydrate.

Soil nitrate $\mathrm{N}\left(\mathrm{NO}_{3}^{-}-\mathrm{N}\right)$ was determined colorimeterically by using salicylic acid nitration method (Cataldo et al., 1975) while soil ammonium $\mathrm{N}\left(\mathrm{NH}_{4}^{+}-\mathrm{N}\right)$ was determined by using Indophenol blue method (Keeney \& Nelson, 1982).

\section{Statistical analyses}

Since all the litter addition treatments showed markedly higher soil respiration rates, all the statistical analyses were performed by grouping litter amended treatments separate from those not amended with litter. However, control soil treatment was included in both types of tests. One-way ANOVA was used to test the effect of treatments on cumulative soil respiration, water extractable organic $\mathrm{C}$, microbial biomass and soil $\mathrm{NO}_{3}^{-}-\mathrm{N}$ and $\mathrm{NH}_{4}^{+}-\mathrm{N}$ content. Least significance difference (LSD) was used to differentiate the treatments means when treatment effect was significant (i.e., $P$ value $<0.05$ ). 


\section{RESULTS}

Reactive Black 5 azo dye contamination did not have any effect on cumulative soil respiration (Fig. 1A). However, RB-5 decolorizing bacteria (Pseudomonas sp. RA20), when added alone or in presence of dye contamination, significantly reduced the soil respiration. All treatments involving litter amendment showed significantly much higher cumulative soil respiration than control (Fig. 2B). On average, all litter amended soils released 5x more $\mathrm{C}$ than the treatments excluding litter.

Availability of water extractable organic carbon (WEOC) or soluble $\mathrm{C}$ did not differ between control and treated soils (Figs. 2A \& 2B, $P>0.05$ ). Moreover, litter treatments did not differ from non-litter treatments in terms of soluble $C(P>0.05)$. Similarly, no treatment, whether involving litter amendment or not, induce any change in microbial biomass (Figs. 2C \& 2D, $P>0.05$ ).

The soil $\mathrm{NO}_{3}^{-}-\mathrm{N}$ content remained unchanged under all the treatments where litter was not added (Fig. 3A, $P>0.05$ ). However, litter addition alone or in combination significantly decreased soil $\mathrm{NO}_{3}^{-}-\mathrm{N}$ content (Fig. 3B, $P<0.05$ ). The decrease was substantial and $\mathrm{NO}_{3}^{-}-\mathrm{N}$ content were undetectable in the dye + bacteria + litter treatment. Among treatments without litter addition, dye addition did not change soil ammonium content (Fig. 3C). However, soil $\mathrm{NH}_{4}^{+}-\mathrm{N}$ content were significantly higher in bacteria and dye + bacteria treatments. Among treatments with litter addition, highest $\mathrm{NH}_{4}^{+}-\mathrm{N}$ was found in dye + bacteria + litter treatment followed dye + litter and control treatments (Fig. 3D, $P<0.05$ ). Lowest $\mathrm{NH}_{4}^{+}-\mathrm{N}$ was found in litter only treatment.

\section{DISCUSSION}

Our short-term study reveals that the azo dye RB-5 does not influence soil organic matter decomposition rates. Increase in soil respiration in response to litter amendment (Fig. 1B) is expected given that litter addition provides labile organic matter to energylimited soil microorganisms (Sanaullah et al., 2010; Pascault et al., 2013; Kaneez-e Batool et al., 2016). The availability of labile carbon may stimulate the local microorganisms to accelerate the decomposition of extant organic matter-a phenomenon known as priming effect (Kuzyakov, Friedel \& Stahr, 2000; Shahzad et al., 2015). In our study, the enormous amount of $\mathrm{CO}_{2}$ liberated (at least $>2,200 \mathrm{mg} \mathrm{CO}_{2} \mathrm{~kg}^{-1}$ soil) in litter amended treatments compared to control soil ( $656 \mathrm{mg} \mathrm{CO} \mathrm{kg}^{-1}$ soil) is a clear indication of priming effect. Dye contamination did not seem to suppress priming effect like overall soil respiration (Fig. 1B).

The decrease in soil respiration in presence of RB-5 decolorizing bacteria i.e., Pseudomonas sp. RA20 (Fig. 1A) was unexpected. In soils, there are several different functional groups of microorganisms which are in constant competition over resources and adapt and evolve in response to environmental changes (Fontaine, Mariotti \& Abbadie, 2003; Shahzad et al., 2012; Perveen et al., 2014). We speculate that over the duration of our experiment, the introduced Pseudomonas sp. isolated and cultured from a stressful (industrial wastewater) environment, might have been stronger at competing for the resources than local microorganisms thereby decreasing their activity, i.e., soil 


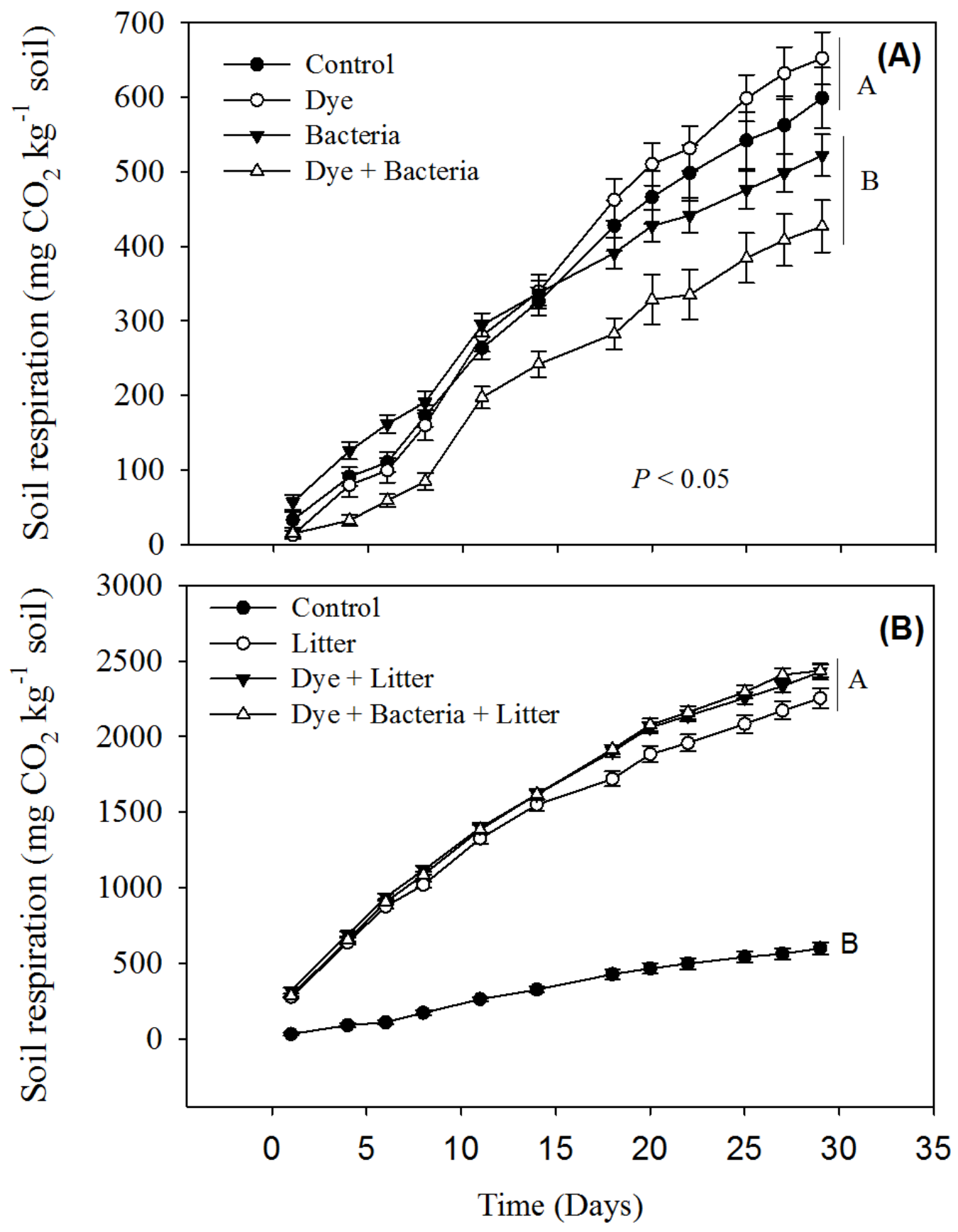

Figure 1 Soil respiration from different treatments. Soil respiration in response to dye, dye + bacteria and bacteria amendments in (A) the absence of and (B) presence of litter supply.

Full-size DOI: $10.7717 /$ peerj.4802/fig-1

respiration. We recommend future studies whereby competition of microorganisms isolated from stressful environments be studied with the microorganisms found in stressfree environments for determining the risk of inoculating such biological resources to local flora. 

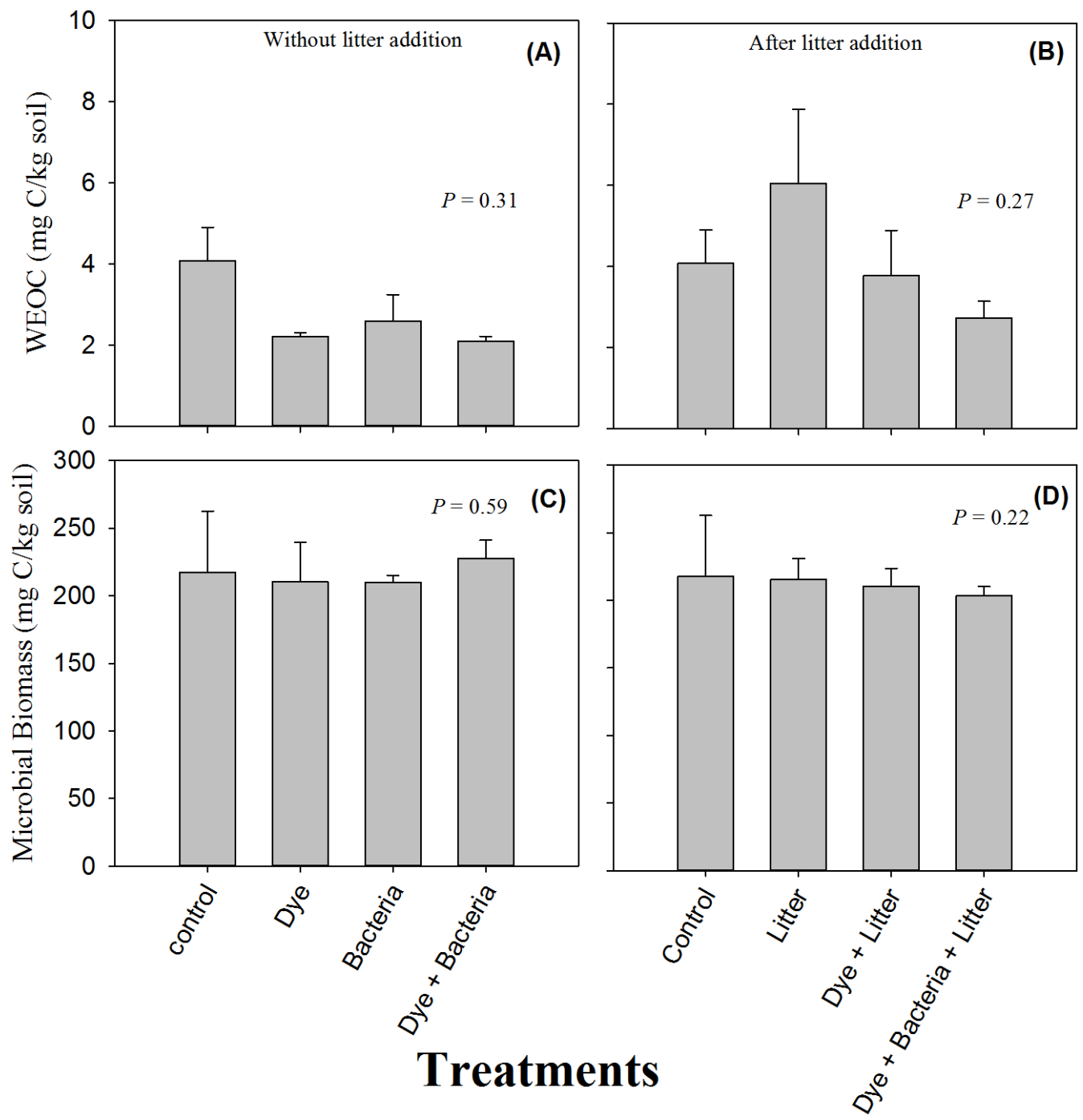

Figure 2 Water extractable organic $\mathrm{C}$ and microbial biomass. Water extractable organic carbon $(\mathrm{C})$ and microbial biomass found in amended soils in (A \& C) the absence and (B \& D) the presence of litter supply respectively. Error bars are standard error of means.

Full-size DOI: 10.7717/peerj.4802/fig-2

Azo dye did not induce any change in the availability of soil inorganic $\mathrm{N}$ in contradiction to previous studies (Topaç et al., 2009; Batool et al., 2015). Markedly reduced soil $\mathrm{NO}_{3}^{-}-\mathrm{N}$ in litter amended soils is an indication of microbial immobilization of soil nitrates to consume the available labile $\mathrm{C}$ to meet their stoichiometric demands of $\mathrm{C}$ and $\mathrm{N}$ (Moritsuka et al., 2004; Bengtson \& Bengtsson, 2005; Shahzad et al., 2012).

Given that this is the first study which investigated soil $\mathrm{C}$ cycling under azo dye contamination, comparisons are impossible to make. However, the effect of azo dye contamination on $\mathrm{N}$ cycling which is closely linked with $\mathrm{C}$ cycling to the point that soil organic matter decomposition is positively related to inorganic $\mathrm{N}$ availability (Drake et al., 2011; Gärdenäs et al., 2011; Shahzad et al., 2015), has been extensively studied and may 

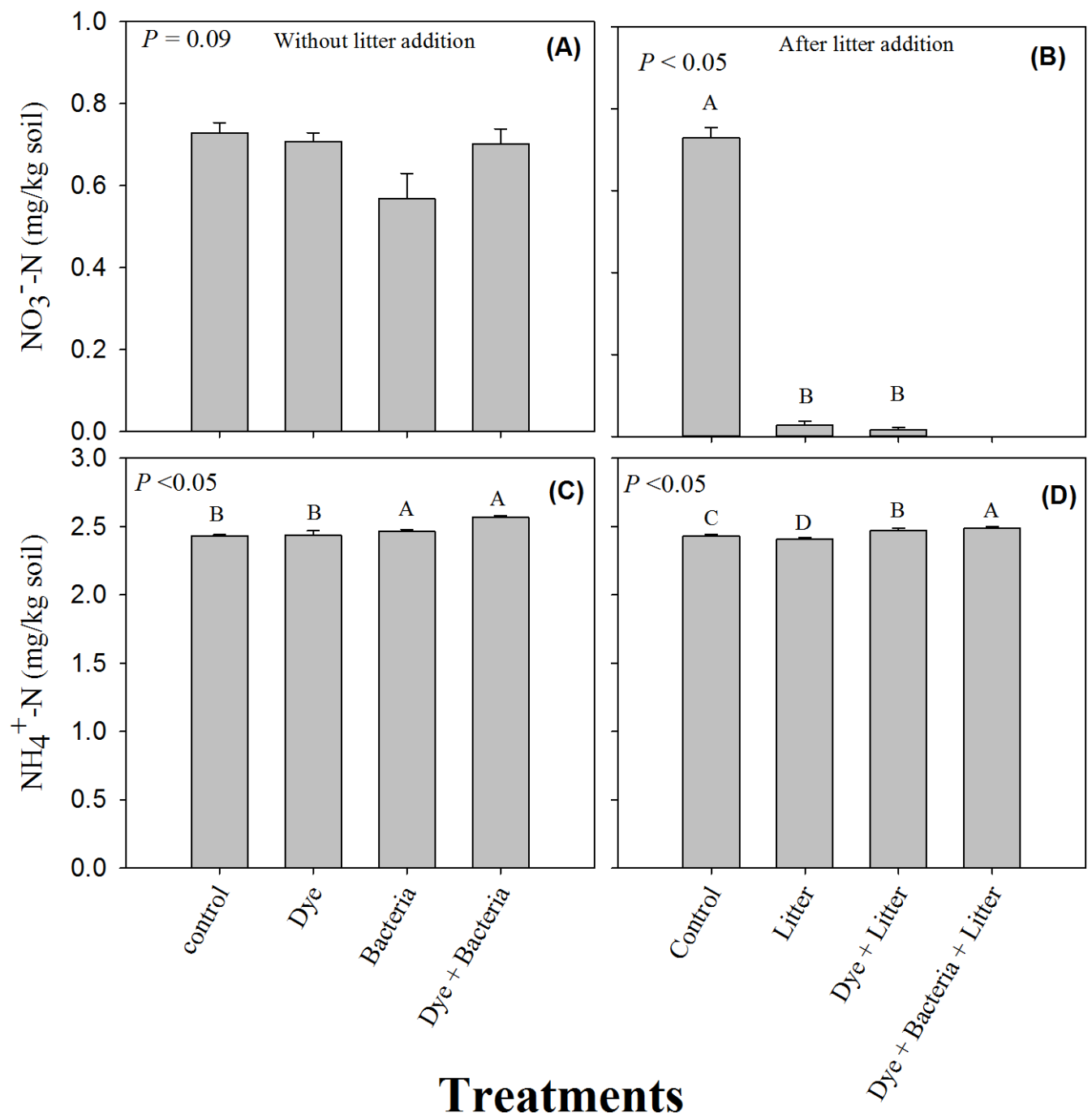

\section{Treatments}

Figure 3 Mineral Nitrogen (ammonium and nitrate). Extractable nitrate and ammonium in amended soils in (A \& C) the absence and (B \& D) the presence of litter supply respectively. Error bars are standard error of means.

Full-size DOI: 10.7717/peerj.4802/fig-3

provide some comparisons. Azo dye contamination has been shown to result in reduction of inorganic $\mathrm{N}$ availability, lower rates of $\mathrm{N}$ transformation events, and reduced number of microorganisms and activity of enzymes involved in N (Topaç et al., 2009; Batool et al., 2015). Briefly, Topaç et al. (2009) found that RB5 (>20 $\mathrm{mg} \mathrm{kg}^{-1}$ dry soil) and sulfonated azo dye ( $>8 \mathrm{mg} \mathrm{kg}^{-1}$ dry soil) decreased urease activity, arginine ammonification rate, nitrification potential and ammonium oxidizing bacteria numbers by $10-20 \%$ and $7-28 \%$, respectively. The azo dye dose applied in their study is comparable to that in our study, i.e., $30 \mathrm{mg} \mathrm{kg}^{-1}$ dry soil. Perhaps the difference in soil texture could explain varying effect of the azo dye on soil processes. The soil we used was a silt loam while they used a sandy clay loam and differing stabilization of azo dyes might have resulted in varying effect on microbial processes (Imran et al., 2015). However, no effect on the microbial activity 
involved in organic matter decomposition found in our study warrant further research. In contrast, the doses of azo dyes in the study of Batool et al. (2015) where they recorded very high decreases in ammonium oxidation process and ammonia oxidizing bacteria numbers (>90\%) were very high (400-1,600 $\mathrm{mg} \mathrm{kg}^{-1}$ dry soil). Low dose of azo dye contamination in our study may explain our contradictory results vis-à-vis those of Batool et al. (2015).

No effect of azo dye contamination on soil microbial biomass was unexpected given that previous studies have repeatedly found reduced numbers of microorganisms in azo dye contaminated soils. For example, Imran et al. (2015) found reduced microbial biomass in the presence of all the three azo dyes including RB 5 that they used in their study. Perhaps the dose in our study was too low to have any deleterious effect on microorganisms because the dose used by Imran et al. (2015) was very high ( $160 \mathrm{mg} \mathrm{kg}^{-1}$ dry soil).

\section{CONCLUSION}

In conclusion, our study shows that low levels of azo dye contamination $\left(30 \mathrm{mg} \mathrm{kg}^{-1}\right.$ dry soil) does not influence respiration or microbial biomass in a silt loam soil. However, we suggest that larger studies involving all the prominent azo dye types used in textile industries with a range of doses and different soil textures should be conducted to simultaneously determine the changes in closely linked $\mathrm{C}$ and $\mathrm{N}$ cycling processes. Moreover, we also propose that the effect of mixtures of azo dyes should be studied in future at different salinity levels mimicking the saline nature of textile wastewater commonly found.

\section{ADDITIONAL INFORMATION AND DECLARATIONS}

\section{Funding}

This work was funded by Higher Education Commission of Pakistan through grant no. PD-IPFP/HRD/HEC/2013/1986. The funders had no role in study design, data collection and analysis, decision to publish, or preparation of the manuscript.

\section{Grant Disclosures}

The following grant information was disclosed by the authors:

Higher Education Commission of Pakistan: PD-IPFP/HRD/HEC/2013/1986.

\section{Competing Interests}

The authors declare there are no competing interests.

\section{Author Contributions}

- Khadeeja Rehman conceived and designed the experiments, performed the experiments, contributed reagents/materials/analysis tools, prepared figures and/or tables, authored or reviewed drafts of the paper, approved the final draft.

- Tanvir Shahzad conceived and designed the experiments, performed the experiments, analyzed the data, contributed reagents/materials/analysis tools, authored or reviewed drafts of the paper, approved the final draft, revised the manuscript. Co-ordinated the whole experiment and manuscript write up. 
- Amna Sahar performed the experiments, authored or reviewed drafts of the paper, approved the final draft.

- Sabir Hussain conceived and designed the experiments, authored or reviewed drafts of the paper, approved the final draft.

- Faisal Mahmood analyzed the data, contributed reagents/materials/analysis tools, prepared figures and/or tables, authored or reviewed drafts of the paper, approved the final draft.

- Muhammad H. Siddique and Muhammad I. Rashid analyzed the data, authored or reviewed drafts of the paper, approved the final draft.

- Muhammad A. Siddique conceived and designed the experiments, authored or reviewed drafts of the paper, approved the final draft.

\section{Data Availability}

The following information was supplied regarding data availability:

The data are provided as Supplemental Files.

\section{Supplemental Information}

Supplemental information for this article can be found online at http://dx.doi.org/10.7717/ peerj.4802\#supplemental-information.

\section{REFERENCES}

\section{Anwar F, Hussain S, Ramzan S, Hafeez F, Arshad M, Imran M, Maqbool Z,} Abbas N. 2014. Characterization of reactive Red-120 decolorizing bacterial strain Acinetobacter junii FA10 capable of simultaneous removal of azo dyes and hexavalent chromium. Water, Air, \& Soil Pollution 225:Article 2017 DOI 10.1007/s11270-014-2017-7.

Batool S, Khalid A, Jalal KCA, Sarfraz M, Balkhair KS, Ashraf MA. 2015. Effect of azo dye on ammonium oxidation process and ammonia-oxidizing bacteria (AOB) in soil. RSC Advances 5:34812-34820 DOI 10.1039/C5RA03768A.

Bengtson P, Bengtsson G. 2005. Bacterial immobilization and remineralization of $\mathrm{N}$ at different growth rates and N concentrations. FEMS Microbiology Ecology 54:13-19 DOI 10.1016/j.femsec.2005.02.006.

Cataldo DA, Maroon M, Schrader LE, Youngs VL. 1975. Rapid colorimetric determination of nitrate in plant tissue by nitration of salicylic acid. Communications in Soil Science and Plant Analysis 6:71-80 DOI 10.1080/00103627509366547.

Cicek N, Efeoglu B, Tanyolac D, Ekmekci Y, Stasser RJ. 2012. Growth and photochemical responses of three crop species treated with textile azo dyes. Turkish Journal of Botany 36:529-537 DOI 10.1111/j.1461-0248.2011.01593.x.

Drake JE, Gallet-Budynek A, Hofmockel KS, Bernhardt ES, Billings SA, Jackson RB, Johnsen KS, Lichter J, Mccarthy HR, Mccormack ML, Moore DJP, Oren R, Palmroth S, Phillips RP, Pippen JS, Pritchard SG, Treseder KK, Schlesinger WH, Delucia EH, Finzi AC. 2011. Increases in the flux of carbon belowground stimulate 
nitrogen uptake and sustain the long-term enhancement of forest productivity under elevated $\mathrm{CO}_{2}$. Ecology Letters 14:349-357 DOI 10.1111/j.1461-0248.2011.01593.x.

Ensink JHJ, Mahmood T, Van der Hoek W, Raschid-Sally L, Amerasinghe FP. 2004. A nationwide assessment of wastewater use in Pakistan: an obscure activity or a vitally important one? Water Policy 6:197-206.

Ensink JHJ, Van der Hoek W, Amerasinghe FP. 2006. Giardia duodenalis infection and wastewater irrigation in Pakistan. Transactions of the Royal Society of Tropical Medicine and Hygiene 100:538-542 DOI 10.1016/j.trstmh.2005.08.014.

Faryal R, Tahir F, Hameed A. 2007. Effect of wastewater irrigation on soil along with its micro and macro flora. Pakistan Journal of Botany 39:193-204

DOI 10.1016/S0038-0717(03)00123-8.

Fontaine S, Mariotti A, Abbadie L. 2003. The priming effect of organic matter: a question of microbial competition? Soil Biology and Biochemistry 35:837-843 DOI 10.1016/S0038-0717(03)00123-8.

Gärdenäs AI, Ågren GI, Bird JA, Clarholm M, Hallin S, Ineson P, Kätterer T, Knicker H, Nilsson SI, Näsholm T, Ogle S, Paustian K, Persson T, Stendahl J. 2011. Knowledge gaps in soil carbon and nitrogen interactions-from molecular to global scale. Soil Biology and Biochemistry 43:702-717 DOI 10.1016/j.soilbio.2010.04.006.

Garg VK, Kaushik P. 2008. Influence of textile mill wastewater irrigation on the growth of sorghum cultivars. Applied Ecology and Environmental Research 6:1-12 DOI 10.1080/19443994.2012.748637.

Gupte S, Keharia H, Gupte A. 2013. Toxicity analysis of azo Red BS and Methyl Red dye solutions on earthworm (Pheretima phosthuma), micro-organisms, and plants. Desalination and Water Treatment 51:4556-4565 DOI 10.1080/19443994.2012.748637.

Hussain S, Maqbool Z, Ali S, Yasmeen T, Imran M, Mahmood F, Abbas F. 2013. Biodecolorization of Reactive Black- 5 by a metal and salt tolerant bacterial strain Pseudomonas sp. RA20 isolated from Paharang drain effluents in Pakistan. Ecotoxicology and Environmental Safety 98:331-338 DOI 10.1016/j.ecoenv.2013.09.018.

Imran M, Shaharoona B, Crowley DE, Khalid A, Hussain S, Arshad M. 2015. The stability of textile azo dyes in soil and their impact on microbial phospholipid fatty acid profiles. Ecotoxicology and Environmental Safety 120:163-168 DOI 10.1016/j.ecoenv.2015.06.004.

Isermeyer H. 1952. Eine einfache Methode zur Bestimmung der Bodenatmung und der Carbonate im Boden. Z Pflanzenernaehr Dueng. Bodenk. 56:26-38 DOI 10.1002/jpln.19520560107.

Jaggi W. 1976. Die Bestimmung der COz-Bildung als Mag der bodenbiologischen Aktivitat. Schw Landw Forsch 15:371-380 DOI 10.1080/03650340.2016.1145792.

Kaneez-e Batool N, Shahzad T, Mahmood F, Hussain S, Riaz M, Maqbool Z, Anwar F, Rehman K, Rashid MI. 2016. Carbon mineralization in response to nitrogen and litter addition in surface and subsoils in an agroecosystem. Archives of Agronomy and Soil Science 62:1285-1292 DOI 10.1080/03650340.2016.1145792. 
Keeney DR, Nelson DW. 1982. Nitrogen—inorganic forms. In: Page AL, Miller RH, eds. Methods of soil analysis, part 2. Second Edition. Madison: American Society of Agronomy, 643-698.

Khalid A, Arshad M, Crowley DE. 2008. Accelerated decolorization of structurally different azo dyes by newly isolated bacterial strains. Applied Microbiology and Biotechnology 78:361-369 DOI 10.1007/s00253-007-1302-4.

Khalid A, Saba B, Kanwal H, Nazir A, Arshad M. 2013. Responses of pea and wheat to textile wastewater reclaimed by suspended sequencing batch bioreactors. International Biodeterioration and Biodegradation 85:550-555

DOI 10.1016/j.ibiod.2013.05.007.

Kuzyakov Y, Friedel J, Stahr K. 2000. Review of mechanisms and quantification of priming effects. Soil Biology and Biochemistry 32:1485-1498 DOI 10.1016/S0038-0717(00)00084-5.

Lal R. 2004. Soil carbon sequestration impacts on global climate change and food security. Science 304:1623-1627 DOI 10.1126/science.1097396.

Lee SH, Oh BI, Kim J. 2008. Effect of various amendments on heavy mineral oil bioremediation and soil microbial activity. Bioresource Technology 99:2578-2587 DOI 10.1016/j.biortech.2007.04.039.

Li Y, Shi JQ, Qu RJ, Feng MB, Liu F, Wang M, Wang ZY. 2012. Toxicity assessment on three direct dyes (D-BLL, D-GLN, D-3RNL) using oxidative stress bioassay and quantum parameter calculation. Ecotoxicology and Environmental Safety 86:132-140 DOI 10.1016/j.ecoenv.2012.09.023.

Mahmood F, Shahid M, Hussain S, Shahzad T, Tahir M, Ijaz M, Hussain A, Mahmood K, Imran M, Babar SAK. 2017. Potential plant growth-promoting strain Bacillus sp. SR-2-1/1 decolorized azo dyes through NADH-ubiquinone: oxidoreductase activity. Bioresource Technology 235:176-184 DOI 10.1016/j.biortech.2017.03.098.

Maliszewska-Kordybach B, Smreczak B. 2000. Ecotoxicological activity of soils polluted with polycyclic aromatic hydrocarbons (PAHs) —effect on plants. Environmental Technology 21:1099-1110 DOI 10.1080/09593330.2000.9618996.

McMullan G, Meehan C, Conneely A, Kirby N, Robinson T, Nigam P, Banat IM, Marchant R, Smyth WF. 2001. Microbial decolourisation and degradation of textile dyes. Applied Microbiology and Biotechnology 56:81-87 DOI 10.1007/s002530000587.

Moritsuka N, Yanai J, Mori K, Kosaki T. 2004. Biotic and abiotic processes of nitrogen immobilization in the soil-residue interface. Soil Biology and Biochemistry 36:1141-1148 DOI 10.1016/j.soilbio.2004.02.024.

Najme R, Hussain S, Maqbool Z, Imran M, Mahmood F, Yasmeen T, Shahzad T. 2015. Biodecolorization of Reactive Yellow-2 by Serratia sp. RN34 isolated from textile wastewater. Water Environment Research 87:2065-2075 DOI 10.2175/106143015X14362865226031.

Nelson DW, Sommers LE. 1982. Total carbon, organic carbon and organic matter. In: Sparks DL, ed. Method of soil analysis. Madison: Amercian Society of Agronomy, 961-1010. 
O’Neill C, Hawkes FR, Hawkes DL, Lourenço ND, Pinheiro HM, Delée W. 1999. Colour in textile effluents—sources, measurement, discharge consents and simulation: a review. Journal of Chemical Technology and Biotechnology 74:1009-1018 DOI 10.1002/(SICI)1097-4660(199911)74:11<1009::AID-JCTB153>3.0.CO;2-N.

Oranusi NA, Ogugbue JC. 2002. Toxic response of Nitrobacter to Orange II and Direct Blue 71. Journal of Applied Sciences and Environmental Management 6:87-90.

Pandey A, Singh P, Iyengar L. 2007. Bacterial decolorization and degradation of azo dyes. International Biodeterioration \& Biodegradation 59:73-84

DOI 10.1016/j.ibiod.2006.08.006.

Pascault N, Ranjard L, Kaisermann A, Bachar D, Christen R, Terrat S, Mathieu $O$, Lévêque J, Mougel C, Henault C, Lemanceau P, Péan M, Boiry S, Fontaine S, Maron PA. 2013. Stimulation of different functional groups of bacteria by various plant residues as a driver of soil priming effect. Ecosystems 16:810-822 DOI 10.1007/s10021-013-9650-7.

Perveen N, Barot S, Alvarez G, Klumpp K, Martin R, Rapaport A, Herfurth D, Louault F, Fontaine S. 2014. Priming effect and microbial diversity in ecosystem functioning and response to global change: a modeling approach using the SYMPHONY model. Global Change Biology 20:1174-1190 DOI 10.1111/gcb.12493.

Sanaullah M, Chabbi A, Leifeld J, Bardoux G, Billou D, Rumpel C. 2010. Decomposition and stabilization of root litter in top- and subsoil horizons: what is the difference? Plant and Soil 338:127-141 DOI 10.1007/s11104-010-0554-4.

Shafqat M, Khalid A, Mahmood T, Siddique MT, Han J, Habteselassie MY. 2017. Evaluation of bacteria isolated from textile wastewater and rhizosphere to simultaneously degrade azo dyes and promote plant growth. Journal of Chemical Technology and Biotechnology 92:2760-2768.

Shahzad T, Chenu C, Genet P, Barot S, Perveen N, Mougin C, Fontaine S. 2015. Contribution of exudates, arbuscular mycorrhizal fungi and litter depositions to the rhizosphere priming effect induced by grassland species. Soil Biology and Biochemistry 80:146-155 DOI 10.1016/j.soilbio.2014.09.023.

Shahzad T, Chenu C, Repinçay C, Mougin C, Ollier JL, Fontaine S. 2012. Plant clipping decelerates the mineralization of recalcitrant soil organic matter under multiple grassland species. Soil Biology and Biochemistry 51:73-80 DOI 10.1016/j.soilbio.2012.04.014.

Sponza DT. 2006. Toxicity studies in a chemical dye production industry in Turkey. Journal of Hazardous Materials 138:438-447 DOI 10.1016/j.jhazmat.2006.05.120.

Tejada M, Gonzalez JL, Hernandez MT, Garcia C. 2008. Application of different organic amendments in a gasoline contaminated soil: effect on soil microbial properties. Bioresource Technology 99:2872-2880 DOI 10.1016/j.biortech.2007.06.002.

Topaç FO, Dindar E, Uçaroğlu S, Başkaya HS. 2009. Effect of a sulfonated azo dye and sulfanilic acid on nitrogen transformation processes in soil. Journal of Hazardous Materials 70:1006-1013 DOI 10.1016/j.jhazmat.2009.05.080.

Vafaei F, Khataee AR, Movafeghi A, Salehi-Lisar SY, Zarei M. 2012. Bioremoval of an azo dye by Azolla filiculoides: study of growth, photosynthetic pigments and 
antioxidant enzymes status. International Biodeterioration and Biodegradation 75:194-200 DOI 10.1016/j.ibiod.2012.09.008.

Vance ED, Brookes PC, Jenkinson DS. 1987. An extraction method for measuring soil microbial biomass C. Soil Biology and Biochemistry 19:703-707 DOI 10.1016/0038-0717(87)90052-6.

Weisburger JH. 2002. Comments on the history and importance of aromatic and heterocyclic amines in public health. Mutation Research-Fundamental and Molecular Mechanisms of Mutagenesis 506, 507:9-20 DOI 10.1016/S0027-5107(02)00147-1.

Zhang W, Liu W, Zhang J, Zhao H, Zhang Y, Quan X, Jin Y. 2012. Characterisation of acute toxicity, genotoxicity and oxidative stress posed by textile effluent on zebrafish. Journal of Environmental Sciences 24:2019-2027

DOI 10.1016/S1001-0742(11)61030-9.

Zhou Q. 2001. Chemical pollution and transport of organic dyes in water-soil-crop systems of the Chinese coast. Bulletin of Environmental Contamination and Toxicology 66:784-793. 